\title{
Laboreal
}

Volume 13 NN$^{\circ} 2$ | 2017

Varia

\section{O sistema Taylor e a fisiologia do trabalho professional}

Texto original: Lahy, J.-M. (1916). Le système Taylor el la physiologie du travail professionnel (Introduction). Paris : Masson.

El sistema Taylor y la fisiología del trabajo profesional

Le système Taylor et la physiologie du travail professionnel

Taylor's system and the physiology of the professional work

\section{Jean-Maurice Lahy}

Tradutor. João Viana Jorge

\section{OpenEdition}

Journals

\section{Edição electrónica}

URL: http://journals.openedition.org/laboreal/352

DOI: $10.4000 /$ laboreal.352

ISSN: 1646-5237

\section{Editora}

Universidade do Porto

\section{Refêrencia eletrónica}

Jean-Maurice Lahy, «O sistema Taylor e a fisiologia do trabalho professional », Laboreal [Online], Volume $13 \mathrm{~N}^{\circ} 2$ | 2017, posto online no dia 01 dezembro 2017, consultado o 14 setembro 2020. URL: http://journals.openedition.org/laboreal/352

Este documento foi criado de forma automática no dia 14 setembro 2020.

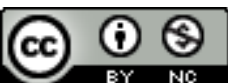

Laboreal está licenciado com uma Licença Creative Commons - Atribuição-NãoComercial 4.0 Internacional 


\title{
O sistema Taylor e a fisiologia do trabalho professional
}

Texto original: Lahy, J.-M. (1916). Le système Taylor el la physiologie du travail professionnel (Introduction). Paris : Masson.

\author{
El sistema Taylor y la fisiología del trabajo profesional \\ Le système Taylor et la physiologie du travail professionnel \\ Taylor's system and the physiology of the professional work
}

\author{
Jean-Maurice Lahy
}

Tradução : João Viana Jorge

\section{Introdução}

1 O homem distingue-se dos seres vivos e desse ser automático que é a máquina pela diversidade quase ilimitada das suas imagens mentais e dos seus gestos e pelas relações que estabelece entre o pensamento e os seus atos com vista a levá-los à perfeição.

Ora, logo que o homem esteja a trabalhar, as suas imagens e gestos reduzem-se às necessidades da sua profissão; o campo da consciência contrai-se. A tendência moderna a limitar a atividade humana a fim de obter uma adaptação precisa dos gestos conduz a uma perda e a um ganho. Se, por um lado a manufatura da matéria prima se realiza nas melhores condições de velocidade e de quantidade e se o operário atinge a perfeição do gesto correlativo da precisão das imagens mentais, por outro lado o excesso de fixidez do pensamento e da ação diminui o indivíduo. Há pois que procurar o ponto de equilíbrio entre o demasiado grande automatismo humano ligado ao trabalho moderno e a dispersão do pensamento devida à ausência de constrangimento.

3 A lei do rendimento acrescido, na medida em que ultrapasse uma duração ótima, vai de encontro ao desenvolvimento psicológico e fisiológico normal do homem. Quanto mais este é constrangido a uma tarefa fixa mais deve gozar, noutros lados, de uma livre iniciativa a fim de reencontrar a multiplicidade de imagens e de realizar pelo seu complexo jogo, atos variados e úteis. 
4 Cada vez que se tratou de organizar o trabalho em novas bases, os reformadores colocaram em primeiro plano o aperfeiçoamento da técnica, não considerando o operário mais do que um elemento da produção, um complemento da ferramenta. Quanto ao campo em que exercerão a sua atividade não especializada, foi sempre ignorado deixando à iniciativa de cada qual o cuidado de encontrar as medidas que preservem o homem e a raça. Daí nasceu para os trabalhadores a necessidade de se agruparem, de agir sem o acordo dos organizadores do trabalho e de a eles se oporem em (caso de) conflitos graves.

5 A obra de W. Taylor é o resultado de uma evolução nas formas de trabalho que não se preocupa senão com o rendimento profissional. $O$ engenheiro americano simplifica os gestos e os métodos de trabalho, não com vista ao bem-estar do operário mas com a finalidade de garantir a sobreprodução de cada um.

6 Esta nova conceção de trabalho está manchada por um triplo erro: psicológico, sociológico e industrial.

7 O operário, ainda que fornecendo à fábrica a maior parte das suas forças e do seu tempo, não deixa de ser um homem cuja ação tende para diversas finalidades. Assimilálo a uma máquina sob o pretexto de que assume uma tarefa em que a parte intelectual é reduzida serve para aumentar ainda mais a sua inferioridade. É a este preconceito, tanto mais revoltante quanto mais, no estado social de hoje, a escolha das profissões não resulta de uma seleção psicológica prévia mas se encontra entregue ao acaso das circunstâncias e ao desprezo com o qual W. Taylor considera os operários das suas fábricas e a hostilidade que, pelo menos em França, acolheu o sistema.

8 Do ponto de vista sociológico o erro é ainda mais grave. Não se pode abstrair o operário do homem que participa em parte da sua atividade social em domínios em que se encontra hierarquicamente melhor colocado do que na fábrica. Chefe de família assume todos os encargos morais que implica a direção de uma casa e a educação de crianças; cidadão, coloca-se por vezes, na vida política, entre os indivíduos mais ativos.

Não é, enfim, cometer um grave erro do ponto de vista profissional, o de não reconhecer o uso cada vez mais expandido da máquina que, substituindo-se ao homem, lhe impõe um trabalho de vigilância, de atenção, de adaptação rápida e segura, para o que as qualidades mentais são indispensáveis?

10 Nada, na obra de W. Taylor indica que tenha tido em conta os diversos pontos de vista que assinalámos. Deixando a outros o cuidado de o criticar segundo os dados da sociologia, pensamos que o psicofisiologista tem o dever, no interesse do patrão como no do operário e mesmo no da raça, de demarcar o lugar do homem em qualquer organização científica do trabalho. A obra de W. Taylor, pelo estudo e a crítica que se lhe possam fazer, permitir-nos-á fixar os elementos essenciais da vida operária e esboçar as linhas de uma organização verdadeiramente científica do trabalho humano que se oponha a métodos demasiado simplistas. Apoiando-nos nos dados da psicofisiologia assinalaremos a importância dos problemas da adaptação operária, da seleção profissional e da fadiga. Ressaltará desse estudo, pensamos nós, o facto de que patrões e operários têm igual interesse em organizar cientificamente o trabalho profissional. 